\title{
Comprehensive performance measurement systems, mental model development, organizational justice, and employee performance: A study in sharia banks
}

\author{
Nurkholis*, Ninda Ayu Wiranti \\ Faculty of Economics and Business, Brawijaya University, Malang, Indonesia \\ *Correspondent author e-mail: nurkholis@ub.ac.id
}

\section{A R T I C LE I N F O}

Article history:

Available online

Keywords:

Comprehensive performance

measurement system, mental model, organizational justice, employee performance

\section{DOI:}

https://doi.org/10.20885/jaai.vol23. iss2.art2
A B S T R A C T

This study aims to examine the effect of implementing a CPMS to the development of mental models, organizational justice, and employee performance using the case of sharia banks. Using survey with convenience sampling method, 63 data were used. Respondents in this study were employees of sharia banks in Malang and Surabaya. Data analysis was run using Structural Equation Model (SEM) with SmartPLS application. The results show that CPMS has a positive effect on the development of mental model and organizational justice. Furthermore, organizational justice has a positive effect on employee performance and mediates the effect of CPMS and employee performance. On the other hand, the development of mental model has no positive effect on employee performance. Thus, the implementation of a CPMS and organizational justice in companies, especially sharia banks, can support the improvement in the employee performance.

\section{Introduction}

The company's performance is related to employee performance. In order to improve employee performance, the company needs a performance measurement system to support employee activities while running operations. Ittner et al. (2003) state that the current trend indicates that many companies develop more comprehensive performance measurement system (CPMS) to communicate the company's strategy to its employees. According to Hall (2011), a CPMS, is a system that provides performance measures that can explain important parts of a company's operations and integrate these measures with the company's strategy and value chain. An important feature of CPMS is the diversity of measurements, where non-financial measurements complement financial measurements to support various aspects of the company's operations (Hall, 2008; Ittner et al., 2003).

This study focuses on understanding the effect of CPMS on the performance of sharia banking employees in Malang and Surabaya. The current development of sharia banking in Indonesia has become a global phenomenon, despite its newly established model. Hesti and Syaichu (2010) argue the growth of sharia banking in Indonesia is the fastest in terms of bank growth, both in sharia product offerings and in asset growth. Until 2010, Sharia banking achieved quite high growth of 35\% (Hesti \& Syaichu, 2010). CNBC Indonesia (2019) added that Abdullah Firman Wibowo as president director of BNI Sharia said that during 2014-2018 Islamic Banking was able to record a Compounded Annual Growth Rate (CAGR) of 15\%, higher than that of the national banking industry which only recorded CAGR just 10\%. However, based on Indonesian Banking Statistics issued on August 2014, there are several financial measures of Indonesian Sharia Banking that have not reached Bank Indonesia (BI) standards. For example, (1) the value of ROA was below the minimum standard of BI $(0.91 \%$ compared to $1.5 \%$ ) and (2) the ratio of operating expenses to operating revenue was slightly above the minimum standard of that set by Bank Indonesia (90.06\% compared to the standard value of $90 \%)$. Therefore, performance measurement system that is able to provide relevant information and support the activities of employees in running the company's business is required.

Several previous studies indicate that a CPMS has an indirect effect on performance (Burney et al., 2009; Chenhall, 2005; Hall, 2008, 2011). Hall (2011) proves that the mental model and development of learning ability can explain the relationship between CPMS and managerial performance. Burney et al. (2009) found the effect of strategic performance measurement systems on incentive plans for employee performance. As has been reviewed, there was no such a study conducted in Sharia Banks, particularly in this country.

This study investigates the effect of CPMS on employee performance through mental model and organizational justice as mediating variables. The purpose of this study is to provide empirical evidence whether: 
(1) a CPMS affects the development of mental models, (2) the development of a mental model affects employee performance, (3) a CMPS affects organizational justice, and 4) organizational justice affects employee performance. The rests of this paper are divided into five sections as follows: literature review, hypothesis formulation, research methods, data analysis, discussion of research results, and conclusion.

\section{Literature Review}

\section{Contingency Theory}

Based on contingency theory, design and implementation of a management control system is influenced by the context or contingency variables on which the system operates and needs to be adapted to the organizational environment (Chenhall, 2003; Fisher, 1998; Rahman et al., 2007). In this study, the management control system is represented by a CPMS. The CPMS explains important aspects of a company's operations and integrate them with the company's strategy. CPMS help improving individual performance in companies if they are compatible with the contingent variables (Chenhall, 2003; Fisher, 1998; Rahman et al., 2007). In some previous studies, contingency variables were divided into two factors, external and internal or organizational and situational (Ganescu, 2012; Haldma \& Lääts, 2002; Lee \& Yang, 2011; Rahman et al., 2007). This study refers to the research of Rahman et al. (2007) which shows that different performance measurement systems in each organization are influenced by organizational and situational factors.

Organizational factors include: size, structure, technology, strategy, as well as external and internal environment of the company. The internal environment of the company has an important role in achieving employee performance, one of which is organizational justice. According to Burney et al. (2009), employees have better performance in a fair work environment. On the other hand, situational factors include individual behavior. According to Jones et al. (2011), mental models are the basis of individual behavior. Mental models reflect beliefs, values, and assumptions underlying individual behavior (Groesser \& Schaffernicht, 2012). Hall (2011) stated that CPMS has a positive effect on managerial performance through the development of mental models. This study uses organizational justice variables and the development of mental models in mediating the influence of a CPMS.

\section{Employee Performance}

Employee performance is the ability of employees to carry out their duties and responsibilities. Employees are considered to have good performance when they are able to meet standards in the job descriptions. Employees performance with traditional systems is often criticized for not being able to provide a comprehensive assessment related to employee behavior and performance (Burney et al., 2009). Therefore, a CPMS that combines financial measures with non-financial measures is needed. A more CPMS can motivate employees to have better performance.

\section{Comprehensive Performance Measurement System}

A CPMS is a system that provides performance measures capable of explaining important aspects of a company's operations and integrates them with the company's value chain and strategy (Hall, 2011). A CPMS communicates company strategy to employees and integrates strategy with company operations and other elements in the enterprise value chain (Chenhall, 2005; Ittner et al., 2003). By integrating performance measures with enterprise strategies and value chains, CPMS provide better business understanding (Hall, 2011). Based on the explanation, the use of a CPMS will have an impact on increased employee performance. Nevertheless, previous research results also found that performance measurement systems have an indirect effect on performance. There are other variables that mediate these relationships, including mental models and organizational justice (Burney et al., 2009; Hall, 2011).

\section{Mental Models}

The mental model is the basis of individual behavior (Jones et al., 2011). The mental model reflects the beliefs, values, and assumptions underlying individual behavior (Groesser \& Schaffernicht, 2012). An individual may use his/her mental model to support reasoning and help solve their problem (Jones et al., 2011). Within the scope of the firm, the mental model is the subjectivity or individual representation in understanding the business operations of a company (Hall, 2011).

\section{Organizational Justice}

Justice is a social value that plays an important role in the environment of society and work (Suliman \& Kathairi, 2013). Aryee et al. (2002) argue that organizational justice describes individual or group perceptions of the 
fairness of the treatment they receive from organizations. There are four constructs to explain organizational justice, namely distributive justice, procedural justice, and interactional justice that are segregated as interpersonal justice and informational justice (Colquitt, 2001). However, the two constructs that were widely used to explain organizational justice are distributive justice and procedural justice (Suliman \& Kathairi, 2013).

\section{Comprehensive Performance Measurement System and Mental Model Development}

CPMS is one of the information provider of the company's business operation thoroughly. Understanding of the company's business operations shapes the employee's mental model. The mental model is the subjectivity or individual representation in understanding the company's business operations (Hall, 2011). Thus, employees with a better understanding of company business operations are better in reasoning and problem solving.

The mental model of employees is made up of work experience and information about the company's business operations (Hall, 2011). The employee's mental model continues to develop with the new information they get. The information develops the mental model in two ways, confirmation of mental models (new information helps to confirm the validity of existing mental models) and construction of mental models (new information forms new mental models) (Hall, 2011). Based on the above explanation, the hypothesis is formulated as follows:

H1: A CPMS positively affects the development of mental models

\section{Development of Mental Models and Employee Performance}

The development of a mental model can enhance the employee's ability to understand the company's environment and deal with situations (Hall, 2011). More specifically, mental models can improve employee's efficiency and productivity to 1) identify and resolve problems and 2) assist employees to maximize their capabilities (March, 1991; Vandenbosch \& Higgins, 1995). Whereas, the development of a mental model helps employees to sharpen the flexibility, creativity, and innovation when facing a competitive environment (March, 1991; Vandenbosch \& Higgins, 1995). Based on the above explanation, the development of mental models leads to increased employee performance. Therefore, the hypothesis is:

$\mathrm{H} 2$ : The development of mental models has a positive effect on employee performance

\section{A System of Comprehensive Performance Measurement and Organizational Justice}

Aryee et al. (2002) argue that organizational justice describes individual or group perceptions of the fairness of the treatment they receive from organizations. The two constructs widely used to explain organizational justice are distributive justice and procedural justice (Suliman \& Kathairi, 2013). Distributive justice reflects the perceptions of fairness relating to the distribution of results that employees receive (salary, promotion and recognition) (Burney et al., 2009). Perceptions of distributive justice are high when employees believe that the ratio between the inputs they provide (time, effort, and expertise) and the results they receive is equal to or beyond the reference ratio (Burney et al., 2009). Procedural justice is the fairness of the procedures used in the decision-making process in the company. Procedures are deemed fair when they are structured in a process that is consistent, accurate, free of bias, ethical, non-rigid, and represents the interests of parties to the procedure (Leventhal, 1980). A CPMS provides employees with the information they need to assess justice in their company. The use of multiple performance indicators in a CPMS can improve the accuracy of the performance appraisal process (Hartmann \& Slapničar, 2012). Based on the above explanation, the hypothesis formulation is as follows:

H3: A CPMS positively affects organizational justice

\section{Organizational Justice and Employee Performance}

Social exchange theory suggests that when an employee feels an individual or an entity is nice to him, then the employee will behave similarly (Aryee et al., 2002; Burney et al., 2009). When employees feel that the company is fair to them, then they will try to improve performance as a form of reciprocity to the company. Burney et al. (2009) also found that when employees feel that they are working in a fair environment, they will work at a higher level. Several previous studies have found a positive relationship between organizational justice and performance. Johnson et al. (2006) provide empirical evidence that employee perceptions of organizational justice affect employee satisfaction, organizational commitment and employee performance. Aryee et al. (2002) found that organizational justice influences work with trust as a mediating variable. Suliman and Kathairi (2013) also conclude that organizational justice (procedural and interactional) is positively related to employee commitment and performance. Based on the explanation, then the hypothesis can be formulated as follows:

H4: Organizational justice positively affects employee performance 


\section{Research Method}

\section{Sample and Data Collection}

Data for this study were collected using primary source with the help of questionnaire survey. A total of 150 questionnaires was distributed to fifteen Sharia Commercial Banks and Sharia Business Unit in Malang and Surabaya. The questionnaires were distributed directly to marketing managers or employees of the banks. Out of the 150 questionnaires distributed, 84 questionnaires were returned, giving a rate of return of $56 \%$. Another effort to following-up the response has been taken by contacting the persons in charge of each bank every two weeks after the distribution of the questionnaire.

However, of 84 returned questionnaires, there were 21 incomplete responses, therefore only 63 in total were useable, giving final response rate of $42 \%$. This rate of return is still within acceptable limits (Baruch \& Holtom, 2008).

\section{Measurement of Variables}

There are four variables in this study namely CPMS, mental model, organizational justice, and employee performance. The questionnaires used were adopted from previous instrument developed by Burney et al. (2009) and Hall (2011). The original (English) version of the questionnaires were firstly translated into Bahasa Indonesia and then discussed with a competent expert to make sure that the translation is correct and not misunderstood by 20 respondents during the pilot test. The result shows that the items for each construct is valid and reliable. Each statement item is presented with a Likert scale of 7 points $(1=$ strongly disagree up to $7=$ strongly agree).

\section{Comprehensive Performance Measurement System}

This research used nine item statements from Hall (2008) to measure the variables of a CPMS. Respondents were asked to assess whether the performance measurement system in their company:

\begin{tabular}{lc}
\multicolumn{1}{c}{ Statement } & Label \\
\hline Provides extensive information on business unit performance from different areas & SPKK1 \\
Created in fully documented form which gives note to evaluate performance & SPKK2 \\
Provides a variety of different performance measures related to key areas performance of the business unit & SPKK3 \\
Connect your business unit's operating performance with long-term strategy the company consistently and & SPKK4 \\
mutually reinforcing & SPKK5 \\
Provide your business unit performance information in different dimensions & SPKK6 \\
Linking your business unit's activities to the achievement of goals and objectives organization & SPKK7 \\
Provides various information about important aspects of your business unit operations & SPKK8 \\
Shows how your business unit affects other business units within the company & SPKK9 \\
Provide measures that can cover (cover) important areas of business unit operations &
\end{tabular}

\section{Development of Mental Models}

This research used seven item statements from Hall (2011) to measure mental model development variables. Respondents were asked to assess the action they are concerned with the development of their mental models.

\begin{tabular}{lc}
\multicolumn{1}{c}{ Statement } & Label \\
\hline Confirmation of the mental model & MM1 \\
My beliefs about my business unit operations are confirmed and supported on a regular basis & MM2 \\
My view of my business unit operating situation is always maintained and validated & MM3 \\
I verify my assumptions about my business unit's operations periodically & MM4 \\
\hline Development of mental models & MM5 \\
I periodically examine and question my assumptions about how my business unit operates & MM6 \\
I often think creatively about the operations of my business unit & MM7 \\
I often change and redirect my thinking about how my business unit operates &
\end{tabular}

\section{Organizational justice}

This research used an 11 item statement from Colquitt (2001) to measure organizational justice variables. Respondents were asked to assess whether each of the following statements is consistent with the distribution of results and decision-making procedures in the company. 


\begin{tabular}{|c|c|}
\hline Statements & Label \\
\hline The results I get (eg salary, rewards, and promotions) reflect the efforts I have put in the work & KO1 \\
\hline The results I get are comparable to the work I have completed & $\mathrm{KO} 2$ \\
\hline The results I get reflect my contribution to the company & $\mathrm{KO} 3$ \\
\hline The results I get are comparable to my performance & $\mathrm{KO} 4$ \\
\hline I can express my views and feelings during the use of company decision-making procedures & KO5 \\
\hline I have influence on the results achieved through the company's decision-making procedures & KO6 \\
\hline The company's decision-making procedures are consistently applied & KO7 \\
\hline The company's decision-making procedures the a company is free of bias & KO8 \\
\hline The company's decision-making procedures are based on accurate information & KO9 \\
\hline I am able to apply for re-consideration of the results achieved, through company decision-making procedures & KO10 \\
\hline The company's decision-making procedures uphold ethical and moral standards & KO11 \\
\hline
\end{tabular}

\section{Employee performance}

The research used seven statement items from Burney et al. (2009) to measure performance. Supervisor asked to assess whether the employee in question does the following:

\begin{tabular}{lc}
\multicolumn{1}{c}{ Statement } & Label \\
\hline Complete the assigned tasks as needed & KK1 \\
Carry out the responsibilities specified in the job description & KK2 \\
Carry out the task in accordance to the expectation & KK3 \\
Meet the formal job performance requirements & KK4 \\
Engage in activities that affect performance evaluation & KK5 \\
Ignore the aspects of the work that must be done & KK6 \\
Failed to perform important tasks & KK7 \\
\hline
\end{tabular}

\section{Partial Least Square Regression (PLS)}

Data analysis was performed using SmartPLS 2.0 M3 software. PLS is one of the statistical methods of Structural Equation Model (SEM) using variable that can be used for problematic data, such as relatively small sample size, data not normally distributed, and missing data (Hair et al., 2012; Hartono \& Abdillah, 2014). In addition, PLS also aims to predict models for theory development (Hartono \& Abdillah, 2014). PLS is used in this study because this research involves theory development and the sample size is relatively small.

\section{Results and Discussion}

\section{Statistics Descriptive}

Demographic information on the study is presented in Table 1 and 2 below. Table 1 shows the demographic information of the respondents based on gender, respondent's age, and tenure. Table 2 shows the descriptive statistics of the research data, such as average value and standard deviation.

Table 1. Demographics of Respondents

Panel A: Demographics of Respondents by Gender

\begin{tabular}{ccc}
\hline Gender & Male & Female \\
\hline Frequency & 32 & 31
\end{tabular}

Panel B: Demographics of Respondents by Age

\begin{tabular}{cccccc}
\hline Years of age & $18-25$ & $26-35$ & $36-45$ & $46-55$ \\
\hline Frequency & 22 & 31 & 8 & 2 \\
Panel C: Demographics of Respondents by Tenure & & & \\
\hline \multicolumn{2}{l}{ Tenure (yrs) } & $<1$ & $>3-5$ & $>5-8$ & $>8$ \\
Kriteria & $<1$ th & $>1-3$ & & Th & Th \\
\hline Frequency & 15 & 20 & 14 & 8 & $>8-10$ th \\
\hline
\end{tabular}

Source: Data Processed 
Table 2. Descriptive Statistics

\begin{tabular}{|c|c|c|c|}
\hline Perception & $\mathrm{N}$ & Mean & Std. Dev. \\
\hline Comprehensive Performance Measurement System (SPKK) & 63 & 5,45 & 1,164 \\
\hline Mental Model (MM) & 63 & 5,39 & 1,186 \\
\hline Organizational Justice (KO) & 63 & 5,08 & 1,350 \\
\hline Employee Performance (KK) & 63 & 5,98 & 0,662 \\
\hline
\end{tabular}

Source: Data Processed

\section{Evaluation of Measurement Models}

The first stage of analysis is the evaluation of the measurement model (outer model) to determine the validity and reliability of the research model. Validity test consists of convergence validity test and discriminant validity test. Convergence validity is determined from AVE score, communality, and loading factor (Hartono \& Abdillah, 2014). In the process of data analysis, it is known that KK5, KK6 and KK7 indicators have loading value less than 0.5 , i.e. $0.040,0.279,0.102$. Therefore, these three indicators are removed from the constructs because they are not contained in the constructs they represent.

Table 3. AVE and Communality

\begin{tabular}{ccc}
\hline & AVE & Communality \\
\hline SPKK & 0.661268 & 0.661268 \\
MM & 0.647896 & 0.647896 \\
KO & 0.661287 & 0.661287 \\
KK & 0.528492 & 0.528492 \\
\hline
\end{tabular}

Source: Data Processed

Notes: SPKK - CPMS, MM - mental model, KO - organizational justice, KK - employee performance.

Table 4. Cross Loadings

\begin{tabular}{ccccc}
\hline & KK & KO & MM & SPKK \\
\hline KK1 & 0.739381 & 0.365908 & 0.124500 & 0.209462 \\
KK2 & 0.811641 & 0.142946 & -0.114262 & 0.049161 \\
KK3 & 0.568920 & 0.045240 & -0.079866 & -0.020943 \\
KK4 & 0.764756 & 0.163799 & -0.042726 & 0.023892 \\
KO1 & 0.155637 & 0.789032 & 0.419475 & 0.444186 \\
KO2 & 0.215578 & 0.868391 & 0.381001 & 0.374627 \\
KO3 & 0.432892 & 0.770180 & 0.236594 & 0.304876 \\
KO4 & 0.260635 & 0.877350 & 0.381701 & 0.395093 \\
KO5 & 0.215869 & 0.851768 & 0.410099 & 0.459627 \\
KO6 & 0.089415 & 0.681185 & 0.479704 & 0.325487 \\
KO7 & 0.329393 & 0.824675 & 0.537128 & 0.599669 \\
KO8 & 0.181483 & 0.749725 & 0.400459 & 0.327897 \\
KO9 & 0.252520 & 0.878187 & 0.575845 & 0.525173 \\
KO10 & 0.184564 & 0.791402 & 0.475039 & 0.467393 \\
KO11 & 0.253414 & 0.839844 & 0.552113 & 0.580531 \\
MM1 & 0.192189 & 0.568022 & 0.794171 & 0.662302 \\
MM2 & 0.054262 & 0.544622 & 0.828560 & 0.733479 \\
MM3 & 0.050880 & 0.527047 & 0.851856 & 0.713720 \\
MM4 & -0.134316 & 0.383370 & 0.785768 & 0.531403 \\
MM5 & -0.057360 & 0.377332 & 0.817685 & 0.619271 \\
MM6 & -0.165423 & 0.230080 & 0.675309 & 0.523808 \\
MM7 & -0.032131 & 0.408010 & 0.866205 & 0.665244 \\
SPKK1 & 0.113932 & 0.545663 & 0.587491 & 0.769248 \\
SPKK2 & 0.164489 & 0.484625 & 0.718739 & 0.850143 \\
SPKK3 & 0.044058 & 0.546163 & 0.728443 & 0.907302 \\
SPKK4 & 0.108651 & 0.387759 & 0.683032 & 0.820438 \\
SPKK5 & 0.130494 & 0.454687 & 0.612211 & 0.784238 \\
SPKK6 & 0.053931 & 0.416451 & 0.667031 & 0.798190 \\
SPKK7 & 0.091597 & 0.335394 & 0.567005 & 0.829301 \\
SPKK8 & 0.317039 & 0.511656 & 0.558918 & 0.728584 \\
SPKK9 & -0.075327 & 0.350750 & 0.685667 & 0.818473 \\
\hline SOur & & &
\end{tabular}

Source: Data Processed

Notes: SPKK - CPMS, MM - mental model, KO - organizational justice, KK - employee performance. 
Table 3 shows that the AVE and communality scores of each construct are above 0.5. From table 4 it is known that there are some indicators with loading scores below 0.7. However, according to Hartono and Abdillah (2014) researchers should not remove the indicator with loading value between $0.5-0.7$ as long as the value of the AVE and Communality indicators is above 0.5. In addition, according to Hair et al. (2012) good value for loading factor is $\geq 0.5$. These results indicate that the convergence validity is approve.

Discriminant validity is determined from loading values and AVE root values compared with correlations between latent variables (Hartono \& Abdillah, 2014). Table 5 shows the AVE root value is greater than the correlation value between constructs. In addition, from table 6 it is known that the loading scores on the constructs that should be measured are larger than in other constructs. These results meet the criterion of discriminant validity.

The reliability of research instruments is determined from the values of Cronbach's alpha and composite reliability (Hartono \& Abdillah, 2014). Table 6 shows that the values of Cronbach's alpha and composite reliability for each variable are greater than 0.7 therefore the criteria for the reliability test is met. Based on these results, the criteria for evaluation of the overall measurement model is met and it can be concluded that the instruments used in this study are valid and reliable.

Table 5. Square Root of AVE and Correlation of Latent Variables

\begin{tabular}{cccccc}
\hline & Square Root of AVE & KK & KO & MM & SPKK \\
\hline KK & 0.726975 & 1 & & & \\
KO & 0.813196 & 0.297120 & 1 & & \\
MM & 0.804920 & -0.003310 & 0.550920 & 1 & 1 \\
SPKK & 0.813184 & 0.128686 & 0.555836 & 0.797842 & 1 \\
\hline
\end{tabular}

Source: Data Processed

Notes: SPKK - CPMS, MM - mental model, KO - organizational justice, KK - employee performance.

Table 6. Composite Reliability and Cronbach's Alpha

\begin{tabular}{ccc}
\hline & Composite Reliability & Cronbach's Alpha \\
\hline SPKK & 0.945971 & 0.935429 \\
MM & 0.927602 & 0.908731 \\
KO & 0.955285 & 0.948514 \\
KK & 0.815231 & 0.728075 \\
\hline
\end{tabular}

Source: Data Processed

Notes: SPKK - CPMS, MM - mental model, KO - organizational justice, KK - employee performance.

\section{Hypothesis Testing}

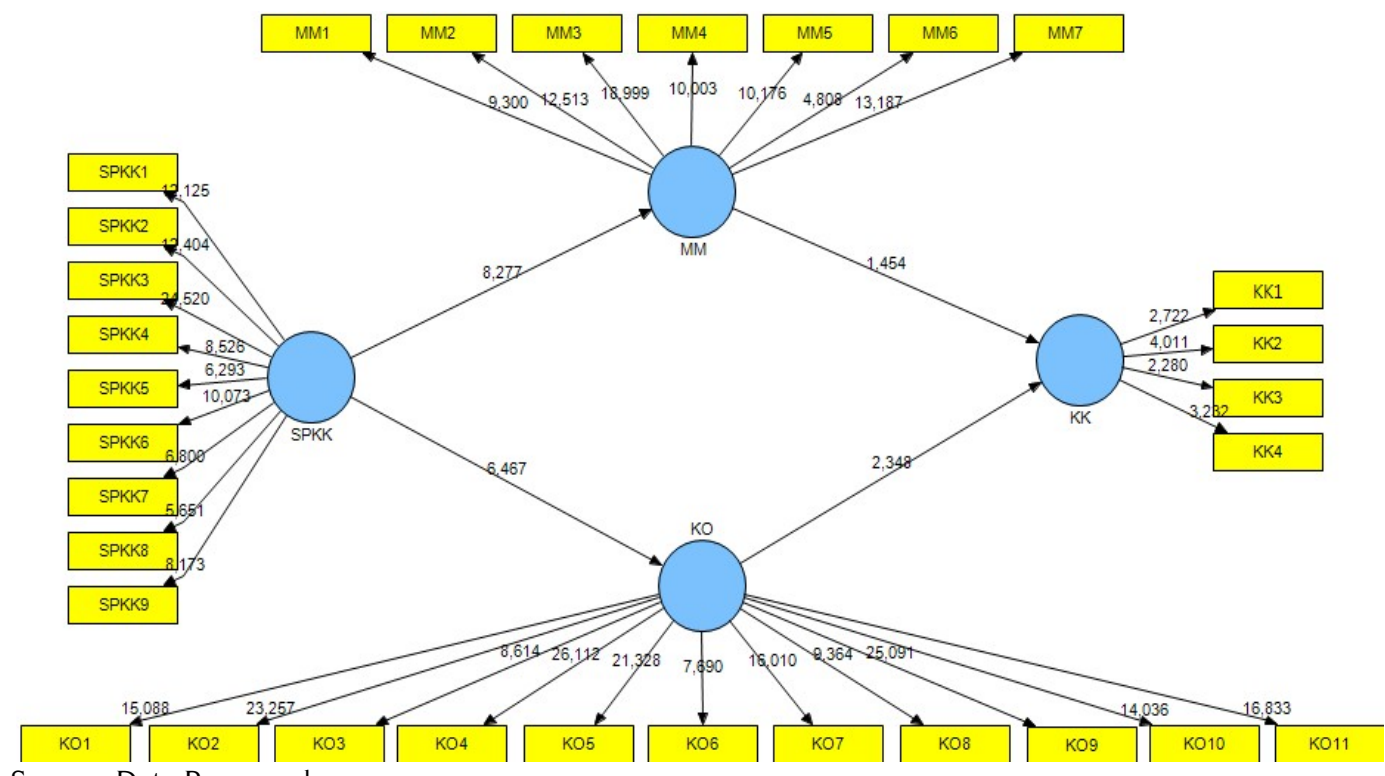

Source: Data Processed

Notes: SPKK - CPMS, MM - mental model, KO - organizational justice, KK - employee performance.

Figure 1. Output Bootstrapping 
The second stage is to evaluate the structural model (inner model) to test the proposed hypothesis. The criteria of hypothesis testing is from the t-statistic value. For a 95\% confidence level, the t-table value for the one-tailed hypothesis is more than or equal to 1.64 ( $\geq 1.64$ ) (Hartono \& Abdillah, 2014). Testing is done by the bootstrapping method available in SmartPLS. Figure 1 shows the bootstrapping output of the research data.

Table 7. Total Effects

\begin{tabular}{cccccc}
\hline & Original Sample & Sample Mean & Standard Deviation & Standard Error & $t$ \\
\hline SPKK $->$ MM & 0.797842 & 0.783875 & 0.096397 & 0.096397 & 8.276675 \\
MM -> KK & -0.239774 & -0.261428 & 0.164883 & 0.164883 & 1.454206 \\
SPKK -> KO & 0.555836 & 0.580769 & 0.085950 & 0.085950 & 6.466959 \\
KO -> KK & 0.429216 & 0.449845 & 0.182817 & 0.182817 & 2.347790 \\
SPKK -> KK & 0.047272 & 0.063116 & 0.133944 & 0.133944 & 0.352922 \\
\hline
\end{tabular}

Source: Data Processed

Notes: SPKK - CPMS, MM - mental model, KO - organizational justice, KK - employee performance.

The first hypothesis (H1) states that a CPMS positively affects the development of mental models. Table 7 shows a positive effect of 0.797 with a t value of $8.276(\geq 1.64)$. Based on these results, $\mathrm{H} 1$ is accepted. The second hypothesis ( $\mathrm{H} 2)$ states that the development of mental models has a positive effect on employee performance. The test results showed a negative effect of -0.239 with a t value of $1.454(<1.64)$. Based on these results, $\mathrm{H} 2$ is rejected. The third hypothesis (H3) states that a CPMS positively affects organizational justice. The test results in Table 7 show a positive effect of 0.555 with a $t$ value of $6.466(\geq 1.64)$. Based on these results, $\mathrm{H} 3$ is accepted. The fourth hypothesis (H4) states that organizational justice has a positive effect on employee performance. The test results showed a positive effect of 0.429 with a t value of $2.347(\geq 1.64)$. Based on these results, $\mathrm{H} 4$ is accepted.

\section{Discussion}

\section{Effect of comprehensive performance measurement system on mental model development}

Acceptance of this hypothesis indicates that the CPMS applied by sharia banking provides relevant information for employees in understanding the business operations of the company. With a CPMS, employees can improve their understanding by evaluating their beliefs, values, and assumptions about the company's business operations. The results of this study are in accordance with previous (Hall, 2011; Vandenbosch \& Higgins, 1995; Yunus \& Yuliansyah, 2012)

The process of developing a mental model takes place in two ways. First, the information presented in a CPMS implemented in sharia banking helps employees to verify and validate employees' beliefs, values, and assumptions about the company's operations. Second, the development of the business environment requires banks to continue to grow. In this case, a CPMS plays a role to provide additional assumptions, values, and new beliefs to existing employee representation.

The development of mental models is obtained by employees not only from the observation process, but also from communication and discussion among members within the company that allows members to exchange experiences. In addition to providing information for employees, a CPMS allows employees to provide feedback. Thus, the performance measurement system also becomes a two-ways communication tool which is an important point of ongoing learning for employees.

\section{Influence of mental model development on employee performance}

Rejection of $\mathrm{H} 2$ indicates that the development of mental models does not provide sufficient evidence to improve employee performance. The results of this study do not fit with previous studies (Hall, 2011; Kosasih \& Budiani, 2007; Kunartinah \& Sukoco, 2010; Makrufah, 2011). These differences can be attributed to differences in research objects or constructs used.

Research by Hall (2011) is aimed at business unit managers, in which the development of mental models greatly influences their performance in decision making. Makrufah (2011), Kunartinah and Sukoco (2010), and Kosasih and Budiani (2007) used organizational learning constructs in their research. Organizational learning has a broader scope than mental models, including personal skills, mental models, shared vision skills, teamwork, and thinking systems (Makrufah, 2011). The wider use of constructs provides greater possibilities for capturing aspects that affect employee performance. 
The development of an employee's mental model may also not necessarily improve performance without being supported by other factors such as leadership style. Jansen (2011) distinguishes leadership styles into two types: transactional leadership and transformational leadership. Transactional leaders define the performance they want to achieve by creating clear targets and rewarding employees with income or bonuses for their satisfactory performance. Conversely, transformational leaders motivate the performance of their employees by communicating the values, beliefs, and mission of the company (Jansen, 2011). Based on these explanations, efforts to improve employee performance is not enough to rely solely on the development of mental models of employees, but it also requires the commitment of leaders in motivating employees by communicating the values, beliefs and mission of the company as an organizational culture or also by giving rewards.

In addition, the effect of a performance measurement system on performance within an enterprise is also depending on what the underlying company is to implement the system and how the company perceives the importance of the system being implemented. Based on institutional theory, the company implements a system as a tool to be accepted by the environment (Eisenhardt, 1988). In implementing the system, the company sees compliance with industry norms, company traditions, and the environment. For example, Eisenhardt (1988) found that public service reform was adopted because it was a symbol of good governance, not because it was efficient. It can also apply to a CPMS. The company applies a CPMS because it is implemented in almost all companies and is a symbol of good corporate governance. The effect of a CPMS on performance is not the main objective of the implementation of the system, but instead is to be accepted by the environment.

\section{Influence of comprehensive performance measurement system to organizational justice}

Acceptance of $\mathrm{H} 3$ indicates that a CPMS implemented in sharia banking can improve employee perceptions of fairness in the corporate environment (distributive justice and procedural justice). The results of this study support Burney et al. (2009).

CPMS involves financial and operational performance, so as to provide more accurate and comprehensive information in the decision-making process, including one of the employee performance appraisal process. By using a CPMS, employee performance is not only judged from financial performance, but also from the operational, such as time discipline, hospitality in serving customers, and so forth. With a more comprehensive appraisal system, employees feel the company is fairer in assessing their performance. The diversity of such information also minimizes the likelihood of bias in the company's decision-making process. In addition, with a CPMS that communicates well about the process and outcomes (rewards) that employees get on their performance, employees can find out how much effort should be spent to get the desired reward and can compare it with initial expectations and conformity with company rules. In addition to creating distributive justice, the above process also creates procedural justice in which employees have an influence in the company's decision-making procedures.

Brata and Juliana (2014) on motorcycle dealership in Pontianak also found that the performance measurement system positively affects the four dimensions of organizational justice, namely distributive, procedural, informational, and interpersonal justice. Performance measurement systems are able to communicate well about the process and outcomes of the corporate reward system so that employees are confident that they are able to track their performance and get the rewards they want. This provides an experience of informational and procedural fairness in the company. The existence of clear communication within the company provides an opportunity for employees to compare rewards earned with the expected rewards, rewards earned by other employees, and conformity with company rules. It makes employees feel distributive justice in the company.

\section{The influence of organizational justice on employee performance}

Acceptance of H4 indicates that employee's perceptions of fairness in the corporate environment can improve employee performance. The results of this study are consistent with previous studies which found a positive influence between organizational justice on employee performance mediated by OCBO (organizational citizenship behaviors organization) variables (Aryee et al., 2002; Burney et al., 2009; Sani, 2013). Increased perceptions of justice, both distributive justice and procedural justice, affect the employee's perspective on the company where he/she works, in this case is sharia banking in Malang and Surabaya.

Fair treatment felt by employees forms a perception that the company respects its employees and takes care of their interests. In accordance with the social exchange theory, as a form of reciprocity for the treatment it receives, the employee will do his best to help the company achieve its objectives. In addition, equity in the distribution of results (salaries, awards, and promotions) as well as fair performance appraisal procedures in sharia banking enables the creation of employee satisfaction and work commitments (Aryee et al., 2002; Johnson et al., 2006; Sani, 2013; Suliman \& Kathairi, 2013). 
The results of this study can be considered for banking in Malang and Surabaya about the importance of organizational justice in the work environment. Justice in this work environment is reflected in, among other things: corporate policy, corporate rules (both written and unwritten), performance measurement system used by the company, or from employers' superior attitudes. Therefore, as an effort to improve employee performance, sharia banking needs to ensure that the above matters reflect organizational justice, both in the distribution of results and in performance appraisal procedures.

\section{Assessing the Development of Mental Model and Organizational Justice as Mediating Variables}

The result of hypothesis testing shows that a CPMS influences employees performance through organizational justice. The results of the test can be seen in Table 5. The Total Effect as presented in Table 7 shows the effect of total predictions (direct and indirect effects) between a CPMS on employee performance. In the table it is seen that a CPMS has a significant effect on the mental model. However, the influence of the mental model on employee performance is not significant $(t=1.454)$. So, it is unable to prove that the mental model mediates the effect of a CPMS on employee performance.

The results also show CPMS significantly influences organizational justice and that organizational justice has significantly affects employee performance. So, it can be concluded that organizational justice mediates the influence of CPMS on employee performance. In addition, Table 7 also shows that the direct effect of CPMS on employee performance is not significant $(t=0.341)$. This indicates that organizational justice mediates the full impact of a CPMS.

Further testing of mediating relationship is run by applying the four steps proposed by Baron and Kenny (1986). The first step is examining the direct relationship between a CPMS with employee performance, and it is found that the relationship is not significant. Significant interrelationships between key variables are one of the conditions that must be met in testing mediating relationships (Baron \& Kenny, 1986; Hartono \& Abdillah, 2014). However, some researchers assume that the direct relationship between the main variables is not necessarily significant in view of the stages required to demonstrate mediation relationships are the $2 \mathrm{nd}$, 3rd and 4th stages (Burney et al., 2009; Preacher \& Hayes, 2008). The second step is examining the relationship between a CPMS with organizational justice, and the results are significant. The third and fourth steps are examining the relationship between a CPMS and organizational justice to employee performance. The third and fourth steps show a non-significant relationship between a CPMS and employee performance, whereas organizational justice to employee performance is significant after being intervened by variable of organizational justice. It can be concluded, therefore, that organizational justice mediates the effect of a CPMS on employee performance.

\section{Conclusion}

This study examines the relationship between CPMS, mental model development, organizational justice, and employee performance in Sharia Banks in Malang and Surabaya. The results provide empirical evidence that the application of CPMS in Sharia Banking can help the learning process of employees by developing employee's mental models. In addition, the use of CPMS helps improve employee perceptions of fairness within the company, both distributive justice and procedural justice.

The results of the research on the development of mental models of employees who have no significant effect on the increase in employee performance indicate that the cause of employees' inability to actualize their maximum potential might be the rules of companies that limit their actions. On the other hand, the development of an employee's mental model may not necessarily improve performance without being backed up with other factors such as leadership style (Jansen, 2011).

The results of this research indicate that the higher the employee perception of fairness in the working environment, the higher the employee performance. This result is in accordance with the social exchange theory, which states that when employees feel the company is fair to them, then they will improve their performance as a form of reciprocity to the company. In addition, mediation effect testing shows that organizational justice mediates the relation between CPMS and employee performance.

The results of this study provides an overview to the company, especially Sharia Banks, about the importance of implementing a more comprehensive PMS on employee performance. This can be used as a consideration in applying a CPMS and know several aspects that need to be emphasized in order to support the improvement of employee performance. It also provides additional empirical evidence of contingency theory and complement previous studies by adding mental model variables and organizational justice in the research model.

The limitations of this study might be on the use of convenience sampling and relatively small size of data ( $n=63)$, although the response rate is considered high and this has been analyzed using PLS as an alternate 
SEM. It is, therefore, suggested that future research use greater sample size using probability sampling techniques in order to result in more generalizable results. Furthermore, the statement items in this questionnaire (research instruments) are adopted without modification in accordance with the object of Sharia Banking. This may because the discussion on the side of sharia became less profound. It is suggested that future research develops specific instruments of CPMS, organizational justice, mental model, and employee performance for Sharia banking industry.

\section{References}

Aryee, S., Budhwar, P. S., \& Chen, Z. X. (2002). Trust as a mediator of the relationship between organizational justice and work outcomes: test of a social exchange model. Journal of Organizational Behavior, 23(3), 267-285.

Baron, R., \& Kenny, D. (1986). The moderator-mediator variable distinction in social psychological research: conceptual, strategic, and statistical considerations. Journal of Personality and Social Psychology, 51(6), 1173-1182.

Baruch, Y., \& Holtom, B. C. (2008). Survey response rate levels and trends in organizational research. Human Relations, 61(8), 1139-1160.

Brata, H., \& Juliana, L. (2014). Performance-based reward systems and perceived justice: A case of motorbike dealer in Pontianak. International Journal of Business and Society, 15(2), 195-214.

Burney, L. L., Henle, C. A., \& Widener, S. K. (2009). A path model examining the relations among strategic performance measurement system characteristics, organizational justice, and extra- and in-role performance. Accounting, Organizations and Society, 34(3-4), 305-321.

Chenhall, R. H. (2003). Management control systems design within its organizational context: findings from contingency-based research and directions for the future. Accounting, Organizations and Society, 28(23), 127-168.

Chenhall, R. H. (2005). Integrative strategic performance measurement systems, strategic alignment of manufacturing, learning and strategic outcomes: An exploratory study. Accounting, Organizations and Society, 30(5), 395-422.

CNBC Indonesia. (2019). 5 Tahun Rerata Pertumbuhan Industri Perbankan Syariah 15\%. CNBC Indonesia. Retrieved from https://www.cnbcindonesia.com/syariah/20190608180708-29-77170/5-tahun-reratapertumbuhan-industri-perbankan-syariah-15

Colquitt, J. A. (2001). On the dimensionality of organizational justice: A construct validation of a measure. Journal of Applied Psychology, 86(3), 386-400.

Departemen Perizinan dan Informasi Perbankan. 2014. Statistik perbankan Indonesia: Agustus 2014. Jakarta. Otoritas Jasa Keuangan.

Eisenhardt, K. M. (1988). Agency- and Institutional-Theory explanations: The case of retail sales compensation. The Academy of Management Journal, 31(3), 488-511.

Fisher, J. G. (1998). Contingency theory, management control systems and firm outcomes: Past results and future directions. Behavioral Research in Accounting, 10, 47-64.

Ganescu, M. C. (2012). Assessing Corporate Social Performance from a Contingency Theory Perspective. In International Conference Emerging Markets Queries in Finance and Business (pp. 999-1004). TîrguMures: Procedia Economics and Finance.

Groesser, S. N., \& Schaffernicht, M. (2012). Mental models of dynamic systems: taking stock and looking ahead. System Dynamics Review, 28(1), 46-68.

Hair, J. F., Sarstedt, M., Pieper, T. M., \& Ringle, C. M. (2012). No TitleaThe Use of Partial Least Squares Structural Equation Modeling in Strategic Management Research: A Review of Past Practices and Recommendations for Future Applications. Long Range Planning, 45(5-6), 320-340.

Haldma, T., \& Lääts, K. (2002). Contingencies influencing the management accounting practices of Estonian manufacturing companies. Management Accounting Research, 13(4), 379-400. 
Hall, M. (2008). The effect of comprehensive performance measurement systems on role clarity, psychological empowerment and managerial performance. Accounting, Organizations and Society, 33(2-3), 141-163.

Hall, M. (2011). Do comprehensive performance measurement systems help or hinder managers' mental model development? Management Accounting Research, 22(2), 68-83.

Hartmann, F., \& Slapničar, S. (2012). The perceived fairness of performance evaluation: The role of uncertainty. Management Accounting Research, 23(1), 17-33.

Hartono, J., \& Abdillah, W. (2014). Konsep Dan Aplikasi PLS (Partial Least Square) Untuk Penelitian Empiris. Yogyakarta: BPFE.

Hesti, D. A., \& Syaichu, M. (2010). Analisis pengaruh ukuran perusahaan, kecukupan modal, kualitas aktiva produktif (KAP), dan likuiditas terhadap kinerja keuangan: Studi pada bank umum syariah di Indonesia periode 2005-2009. Universitas Diponegoro.

Ittner, C. D., Larcker, D. F., \& Randall, T. (2003). Performance implications of strategic performance measurement in financial services firms. Accounting, Organizations and Society, 28(7-8), 715-741.

Jansen, E. P. (2011). The effect of leadership style on the information receivers' reaction to management accounting change. Management Accounting Research, 22(2), 105-124.

Johnson, R. E., Selenta, C., \& Lord, R. G. (2006). When organizational justice and the self-concept meet: Consequences for the organization and its members. Organizational Behavior and Human Decision Processes, 99(2), 175-201.

Jones, N. A., Ross, H., Lynam, T., Perez, P., \& Leitch, A. (2011). Mental models: An interdisciplinary synthesis of theory and methods. Ecology and Society, 16(1), 1-46.

Kosasih, N., \& Budiani, S. (2007). Pengaruh knowledge management terhadap kinerja karyawan: Studi kasus departemen front office Surabaya Plaza Hotel. Jurnal Manajemen Perhotelan, 3(2), 74-84.

Kunartinah, K., \& Sukoco, F. (2010). Pengaruh pendidikan dan pelatihan, pembelajaran organisasi terhadap kinerja dengan kompetensi sebagai mediasi. Jurnal Bisnis Dan Ekonomi, 17(1), 74-84.

Lee, C.-L., \& Yang, H.-J. (2011). Organization structure, competition and performance measurement systems and their joint effects on performance. Management Accounting Research, 22(2), 84-104.

Leventhal, G. S. (1980). What should be done with Equity Theory. Social Exchange, 27-55.

Makrufah, S. (2011). Pengaruh budaya, pembelajaran organisasi terhadap kinerja karyawan Hotel Bumi Surabaya. Jurnal Akuntansi, Manajemen Bisnis Dan Sektor Publik, 8(1), 78-100.

March, J. G. (1991). Exploration and exploitation in organizational learning. Organization Science, 2(1), 71-87.

Preacher, K. J., \& Hayes, A. F. (2008). Asymptotic and resampling strategies for assessing and comparing indirect effects in multiple mediator models. Behavior Research Methods, 40, 879-891.

Rahman, S., Nasir, M., \& Handayani, R. S. (2007). Pengaruh sistem pengukuran kinerja terhadap kejelasan peran, pemberdayaan psikologis dan kinerja manajerial. In Simposium Nasional Akuntansi ke X (pp. 1-35). Makasar: Ikatan Akuntan Indonesia Kompartemen Akuntan Pendidik (IAI KAPd).

Sani, A. (2013). Role of procedural justice, organizational commitment and job satisfaction on job performance: The mediating effects of organizational citizenship behavior. International Journal of Business and Management, 8(15), 57-67.

Suliman, A., \& Kathairi, M. Al. (2013). rganizational justice, commitment and performance in developing countries: The case of the UAE. Employee Relations, 35(1), 98-115.

Vandenbosch, B., \& Higgins, C. A. (1995). Executive support systems and learn-ing: A model and empirical test. Journal of Managements Information Systems, 12(2), 99-130.

Yunus, M., \& Yuliansyah. (2012). Pengaruh penggunaan pengukuran kinerja interaktif terhadap kinerja perusahaan: Peran pembelajaran perusahaan sebagai faktor mediasi. In Simposium Nasional Akuntansi Ke XV (pp. 1-28). Lampung: Ikatan Akuntan Indonesia Kompartemen Akuntan Pendidik (IAI KAPd). 